\title{
Kannanite, a new mineral from Kannan Mountain, Japan
}

\author{
Daisuke Nishio-Hamane$^{*}$, Mariko NAgashima ${ }^{* *}$, Nobuhiro OgaWA ${ }^{* * *}$ and Tetsuo MinaKaWA ${ }^{\dagger}$ \\ *Institute for Solid State Physics, The University of Tokyo, Kashiwa 277-8581, Japan \\ ** Graduate School of Sciences and Technology for Innovation, Yamaguchi University, Yamaguchi 753-8512, Japan \\ ${ }^{* * *}$ Atmosphere and Ocean Research Institute, The University of Tokyo, Kashiwa 277-8564, Japan \\ ${ }^{\dagger}$ Ehime University Museum, Ehime University, Matsuyama, 790-8577, Japan
}

\begin{abstract}
Kannanite, a new Ca-dominant member of the ardennite series, was obtained from Kannan Mountain, Ozu, Ehime Prefecture, Japan. Kannanite occurs in fine quartz veins crossing the hematite-rich regions of an ironmanganese ore included in the metachert. These veins are pale orange in color, while the kannanite itself is brownish-orange to orange, with a thin section exhibiting weak pleochroism. The mineral was found in grain sizes ranging from several to $15 \mu \mathrm{m}$ and has a Mohs hardness of 6 and a calculated density of $3.43 \mathrm{~g} \mathrm{~cm}^{-3}$. The mean refractive index obtained from the Gladstone-Dale relationship for this mineral is 1.788. The empirical formula for kannanite is $\left(\mathrm{Ca}_{3.60} \mathrm{Mn}_{0.40}^{2+}\right)_{\Sigma 4}\left(\mathrm{Al}_{3.00} \mathrm{Mn}_{1.31}^{3+} \mathrm{Fe}_{0.69}^{3+} \mathrm{Mg}_{0.71} \mathrm{Mn}_{0.19}^{2+} \mathrm{Ni}_{0.06} \mathrm{Cu}_{0.05}\right)_{\Sigma 6}\left[\left(\mathrm{~V}_{0.70}^{5+} \mathrm{Si}_{0.16} \mathrm{As}_{0.14}\right)_{\Sigma 1}\right.$ $\left.\mathrm{O}_{3.84}(\mathrm{OH})_{0.16}\right]\left(\mathrm{SiO}_{4}\right)_{2}\left(\mathrm{Si}_{3} \mathrm{O}_{10}\right)(\mathrm{OH})_{6}$, while the simplified formula is $\mathrm{Ca}_{4}\left[\left(\mathrm{Al}, \mathrm{Mn}^{3+}, \mathrm{Fe}^{3+}\right)_{5} \mathrm{Mg}\right]\left(\mathrm{VO}_{4}\right)\left(\mathrm{SiO}_{4}\right)_{2}$ $\left(\mathrm{Si}_{3} \mathrm{O}_{10}\right)(\mathrm{OH})_{6}$. Kannanite has an orthorhombic structure with a space group Pnmm and unit cell parameters $a=8.8802(14) \AA, b=5.9919(13) \AA, c=18.882(3) \AA$ and $V=1004.7(3) \AA^{3}$. Kannanite is considered to be formed by the activities of metamorphic fluid accompanied with the Sanbagawa metamorphism.
\end{abstract}

Keywords: Kannanite, Ardennite, New mineral, Ehime Prefecture, Japan

\section{INTRODUCTION}

To date, two ardennite-series minerals, ardennite-(As) $\mathrm{Mn}_{4}^{2+}\left(\mathrm{Al}_{5} \mathrm{Mg}\right)\left(\mathrm{AsO}_{4}\right)\left(\mathrm{SiO}_{4}\right)_{2}\left(\mathrm{Si}_{3} \mathrm{O}_{10}\right)(\mathrm{OH})_{6}$ and ardennite-(V) $\mathrm{Mn}_{4}^{2+}\left(\mathrm{Al}_{5} \mathrm{Mg}\right)\left(\mathrm{VO}_{4}\right)\left(\mathrm{SiO}_{4}\right)_{2}\left(\mathrm{Si}_{3} \mathrm{O}_{10}\right)(\mathrm{OH})_{6}$, have been identified (Barresi et al., 2007). They occur as rock-forming minerals in oxidized $\mathrm{Mn}$-Al-rich metasediments over a wide range of pressure-temperature conditions (e.g., Pasero et al., 1994). The general formula for ardennite-series minerals can be written as $\mathrm{A}_{4}^{2+}\left(\mathrm{M}_{5}^{3+} \mathrm{M}^{2+}\right)$ $\left(\mathrm{T}^{5+} \mathrm{O}_{4}\right)\left(\mathrm{T}^{4+} \mathrm{O}_{4}\right)_{2}\left(\mathrm{~T}_{3}^{4+} \mathrm{O}_{10}\right)(\mathrm{OH})_{6}$ (e.g., Donnay and Allmann, 1968; Nagashima and Armbruster, 2010). These minerals have orthorhombic symmetry with a space group Pnmm and consist of chains of edge-sharing $\mathrm{MO}_{6}$ octahedra running along the $\boldsymbol{b}$-axis, linked to $\mathrm{TO}_{4}$ and $\mathrm{T}_{3} \mathrm{O}_{10}$ tetrahedral groups via $\mathrm{AO}_{7}$ polyhedra (Fig. 1). There are two A sites for $\mathrm{A}^{2+}$ cations, which are primarily occupied by $\mathrm{Mn}^{2+}$. Among the three octahedral sites, the M1 and M2 sites are occupied only by trivalent cations, while the M3 site is shared by both trivalent and divalent cations, with $\mathrm{M}_{0.5}^{3+} \mathrm{M}_{0.5}^{2+}$ as the ideal occupancy. Si exclusively oc-

\section{doi: $10.2465 /$ jmps. 180103}

D. Nishio-Hamane, hamane@issp.u-tokyo.ac.jp Corresponding author

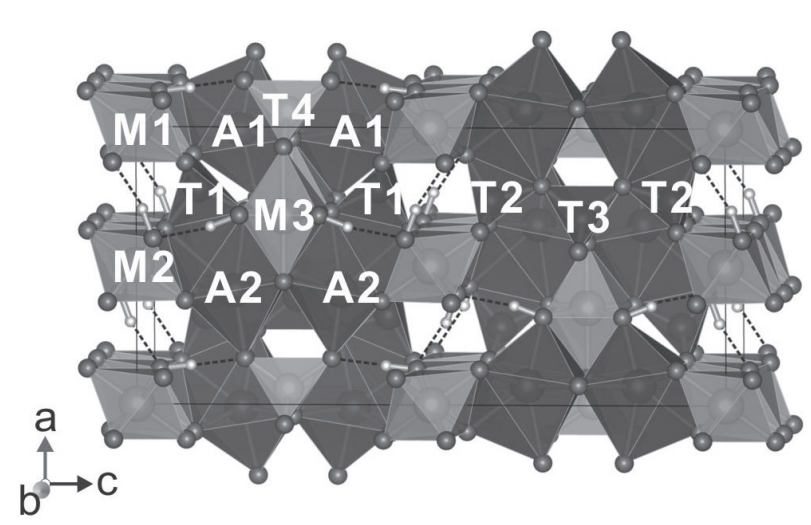

Figure 1. Structure of ardennite-series minerals obtained using VESTA program (Momma and Izumi, 2011).

cupies the T1, T2, and T3 sites, and pentavalent cations such as As and $\mathrm{V}$ dominate at the $\mathrm{T} 4$ site, with lesser amounts of Si also at this site (Nagashima and Armbruster, 2010). Although the $c$ periodicity of ardennite-series minerals is approximately $19 \AA$, anomalous ardennite with a double $c$ periodicity (approximately $37 \AA$ ) has been reported by Pasero and Reinecke (1991). This material was later determined to represent a new mineral called lavoisierite, which has structural features between those 

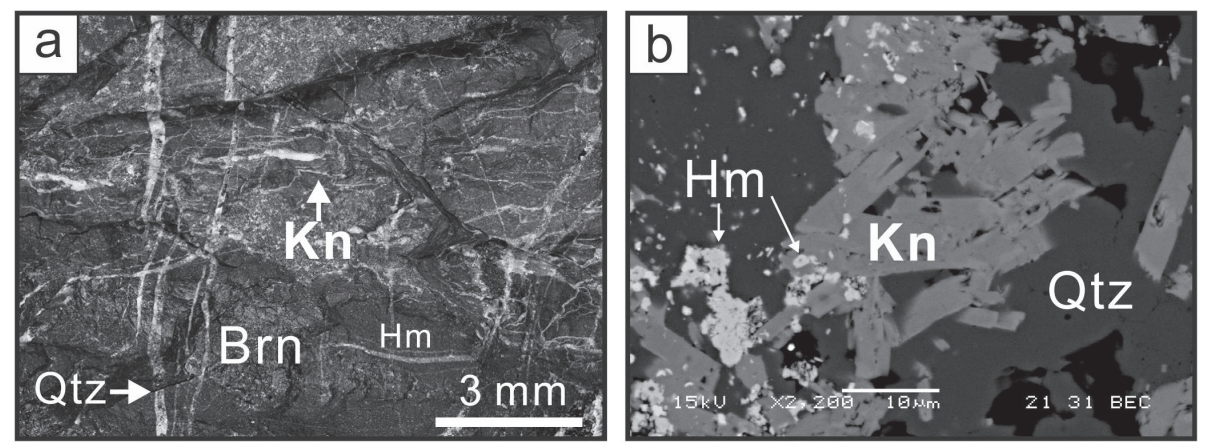

Figure 2. (a) Photographic image of quartz vein containing kannanite in iron-manganese ore sample, and (b) backscattered electron image of kannanite. Legend: Brn, braunite; $\mathrm{Hm}$, hematite; Kn, kannanite; Qtz, quartz. Color version is available online from https://doi.org/10.2465/ jmps. 180103 .

of ardennite and sursassite (Orlandi et al., 2013).

During a mineralogical survey of the iron-manganese deposit on Kannan Mountain in Ehime Prefecture, Japan, our own group collected an ardennite-like mineral from an outcrop. Subsequent studies revealed that the mineral is a new phase of $\mathrm{Ca}$-dominant member of the ardennite series. This mineral was named kannanite after the location where it was found, and both the mineral and name have been approved by the International Mineralogical Association, Commission on New Minerals, Nomenclature and Classification (2015-100). A holotype specimen has been deposited in the collection of the National Museum of Nature and Science, Japan (NSM M-44527).

\section{OCCURRENCE AND GENERAL APPEARANCE}

The Ozu district is located in the western part of Ehime Prefecture on Shikoku Island, Japan. The geology of this district primarily consists of a Jurassic accretionary complex of the Northern Chichibu terrane, Sanbagawa Metamorphic Complex, Miocene dyke, and Quaternary sediments. Banno et al. (2010) divided the Sanbagawa Metamorphic Complex within the Ozu district into six units according to geological features: the Ozu, Nakaidani, Fukuoka, Kannan, Uchiko, and Iyo units.

Kannan Mountain (33⒊ $\left.02 \mathrm{~N} 132^{\circ} 37^{\prime} 58^{\prime \prime} \mathrm{E}\right)$ is located in the southern part of the Ozu district, and it is mainly comprised of metamorphic rocks of the Kannan unit. The Kannan unit corresponds to Mikabu Greestone and consists of metamorphosed basaltic tuff and lava, metagabbro, metadolerite, and metachert. Pumpellyite and actinolite with minor amounts of epidote commonly occur in the mafic rocks, and thus this unit was evidently exposed to metamorphism in the pumpellyite-actinolite facies (e.g., Sakakibara et al., 1998). The metachert is distributed over the southeast side of the mountain and contains small-scale iron-manganese deposits. Our samples were collected from an outcrop of these deposits which occur as a layer of iron-manganese ore in the metachert with a thickness of approximately $50 \mathrm{~cm}$. The ores have a reddish-black coloration and are fragile due to the development of cracks. The ore specimens consist mainly of quartz and hematite, in association with braunite. A fine-grained hematite is scattered throughout the ore, with occasional lenticular aggregates of braunite with thicknesses of several $\mathrm{mm}$ to $5 \mathrm{~cm}$. Apatite occurs as very minor constituent mineral in the ore. The ore sample is penetrated by numerous quartz veins with widths ranging from several $\mu \mathrm{m}$ to $2 \mathrm{~cm}$. Although the majority of these quartz veins is either not accompanied by other minerals or occurs together with piemontite, veins containing orange-colored minerals were found in a part of the specimen (Fig. 2a). These minerals are kannanite and ardennite-(V), and kannanite occurs in fine quartz veins crossing the hematite-rich part. Minor piemontite and hematite also occur in the quartz vein including kannanite and ardennite-(V). The quartz vein with these ardennite-series minerals is also crossed by another pure quartz vein. Kannanite and ardennite-(V) are considered to be formed by the activities of metamorphic fluid accompanied with the Sanbagawa metamorphism.

\section{PHYSICAL AND OPTICAL PROPERTIES}

The quartz vein containing kannanite is pale orange in color (Fig. 2a). Under microscope, kannanite in thin sections exhibits weak pleochroism from orange to brownish orange. The mineral has a vitreous luster, and fluorescence was not observed under short- and long-wavelength ultraviolet light. The grain size is typically several $\mu \mathrm{m}$ and rarely up to $15 \mu \mathrm{m}$. The crystals are fragmented into anhedral grains in most cases, and tabular or columnar shapes were rarely seen during scanning electron microscopy observations (Fig. 2b). In either case, many voids were observed in the crystals. The Mohs hardness of the specimen is 6 , as determined by rubbing the standard powder on a thin section. The cleavage plane for the sample could not be determined due to the small grain sizes, although it is expected to be perfectly along the $\{010\}$ plane by analogy with ardennite-series minerals. The density of this mineral as 


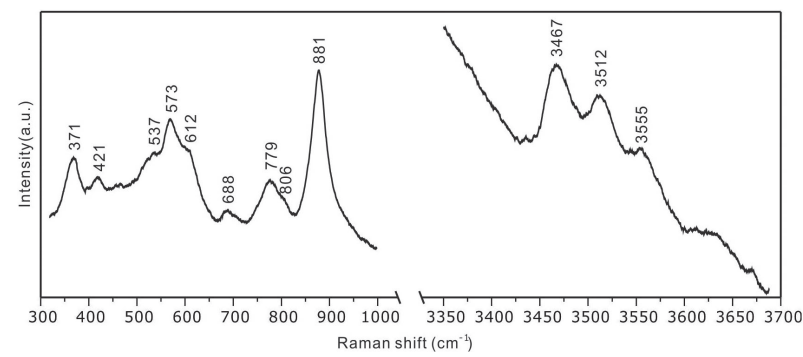

Figure 3. Raman spectra of kannanite.

calculated based on the empirical formula and powder unit cell data is $3.43 \mathrm{~g} \mathrm{~cm}^{-3}$. Although the optical properties were not measured owing to the small grain size, the mean refractive index obtained from the Gladstone-Dale relationship (Mandarino, 1981) using the empirical formula and calculated density is 1.788 .

\section{RAMAN SPECTROSCOPY}

A Raman spectroscopic analysis was performed using a $514.5 \mathrm{~nm}$ argon laser at a power setting of $50 \mathrm{~mW}$ in conjunction with a HORIBA HR320 spectrometer. Peak positions were calibrated using silicon, and the resulting Raman spectra are shown in Figure 3, in which peaks are evident at $300-1000$ and $3300-3700 \mathrm{~cm}^{-1}$ but not in the range of $1000-3000 \mathrm{~cm}^{-1}$. Based on the Fourier transform infrared (FT-IR) analysis of ardennite-(As) by Frost et al. (2014), the peaks may be assigned as follows: $371 \mathrm{~cm}^{-1}$ to $v 2$ symmetric bending vibrations, $421 \mathrm{~cm}^{-1}$ to $v 4$ out-ofplane bending modes for $\mathrm{VO}_{4}$ units, $779-881 \mathrm{~cm}^{-1}$ to $\mathrm{VO}_{4}$ antisymmetric and symmetric stretching vibrations, and $3400-3600 \mathrm{~cm}^{-1}$ to $\mathrm{O}-\mathrm{H}$ stretching vibrations.

\section{CHEMICAL COMPOSITION}

Chemical analyses were carried out using a JEOL JXA8230 electron microprobe (WDS mode, $15 \mathrm{kV}, 20 \mathrm{nA}$, $1 \mu \mathrm{m}$ beam diameter) at the Centre for Instrumental Analysis, Yamaguchi University. The ZAF method was employed for data correction. A JEOL JSM-5600 electron microprobe (EDS mode, $15 \mathrm{kV}, 0.4 \mathrm{nA}, 1 \mu \mathrm{m}$ beam diameter) was also used for chemical analysis. The presence of $\mathrm{OH}$ groups was confirmed by Raman spectroscopy while the $\mathrm{H}_{2} \mathrm{O}$ content was calculated based on stoichiometry because it could not be directly measured due to the paucity of material. Table 1 summarizes the WDS analysis $(n=12)$ of kannanite from a single vein. The $\mathrm{Mn}^{2+} / \mathrm{Mn}^{3+}$ ratio and total $\mathrm{H}_{2} \mathrm{O} \mathrm{wt} \%$ are calculated by the stoichiometry as 28 anions and 16 cations $(\mathrm{Si}+\mathrm{V}+$ As $=6$ and others $=10$ ). The total iron was estimated as $\mathrm{Fe}_{2} \mathrm{O}_{3}$. The total wt $\%$ obtained from these calculations was slightly less than 100, suggesting electron beam dam-
Table 1. Mean chemical composition data $(n=12)$ for kannanite obtained from single vein by electron microprobe analysis

\begin{tabular}{|c|c|c|c|c|}
\hline & wt\% Mean (Min.-Max) & Standards & & \\
\hline $\mathrm{V}_{2} \mathrm{O}_{5}$ & $6.04(5.49-6.53)$ & $\mathrm{Ca}_{3}\left(\mathrm{VO}_{4}\right)_{2}$ & $\mathrm{Ca}$ & 3.60 \\
\hline $\mathrm{As}_{2} \mathrm{O}_{5}$ & $1.52(1.38-1.78)$ & GaAs & $\mathrm{Mn}^{2+}$ & 0.40 \\
\hline $\mathrm{SiO}_{2}$ & $29.37(28.73-29.84)$ & $\mathrm{CaSiO}_{3}$ & $\Sigma \mathrm{A}$ & 4 \\
\hline $\mathrm{Al}_{2} \mathrm{O}_{3}$ & $14.40(13.85-15.13)$ & $\mathrm{Al}_{2} \mathrm{O}_{3}$ & & \\
\hline $\mathrm{Fe}_{2} \mathrm{O}_{3}$ & $5.18(4.83-5.44)$ & $\mathrm{Fe}_{2} \mathrm{O}_{3}$ & $\mathrm{Al}$ & 3.00 \\
\hline $\mathrm{MnO}$ & $12.65(11.86-13.99)$ & $\mathrm{MnO}$ & $\mathrm{Mn}^{3+}$ & 1.31 \\
\hline $\mathrm{CaO}$ & $19.02(17.34-19.68)$ & $\mathrm{CaSiO}_{3}$ & $\mathrm{Mg}$ & 0.71 \\
\hline $\mathrm{MgO}$ & $2.70(2.57-2.82)$ & $\mathrm{MgO}$ & $\mathrm{Fe}^{3+}$ & 0.69 \\
\hline $\mathrm{CuO}$ & $0.34(0.23-0.46)$ & $\mathrm{Cu}$ & $\mathrm{Mn}^{2+}$ & 0.19 \\
\hline $\mathrm{NiO}$ & $0.40(0.30-0.51)$ & $\mathrm{NiO}$ & $\mathrm{Ni}$ & 0.06 \\
\hline Total & 91.62 & & $\mathrm{Cu}$ & 0.05 \\
\hline $\mathrm{MnO}^{*}$ & 3.89 & & $\Sigma \mathrm{M}$ & 6 \\
\hline $\mathrm{Mn}_{2} \mathrm{O}_{3}{ }^{*}$ & 9.74 & & & \\
\hline $\mathrm{H}_{2} \mathrm{O}^{*}$ & 5.22 & & V & 0.70 \\
\hline \multirow[t]{6}{*}{ Total } & 97.83 & & As & 0.14 \\
\hline & & & $\mathrm{Si}$ & 0.16 \\
\hline & & & $\Sigma \mathrm{T} 4$ & 1 \\
\hline & & & $\mathrm{Si}$ & 5 \\
\hline & & & $\mathrm{O}$ & 21.84 \\
\hline & & & $\mathrm{OH}$ & 6.16 \\
\hline
\end{tabular}

${ }^{*}$ Calculated from stoichiometry (28 anions and 16 cations).

age or some effect of voids hidden under the beam spot. The empirical formula for kannanite is $\left(\mathrm{Ca}_{3.60} \mathrm{Mn}_{0.40}^{2+}\right)_{\Sigma 4}$ $\left(\mathrm{Al}_{3.00} \mathrm{Mn}_{1.31}^{3+} \mathrm{Fe}_{0.69}^{3+} \mathrm{Mg}_{0.71} \mathrm{Mn}_{0.19}^{2+} \mathrm{Ni}_{0.06} \mathrm{Cu}_{0.05}\right)_{\Sigma 6}\left[\left(\mathrm{~V}_{0.70}^{5+} \mathrm{Si}_{0.16}\right.\right.$ $\left.\left.\mathrm{As}_{0.14}\right)_{\Sigma 1} \mathrm{O}_{3.84}(\mathrm{OH})_{0.16}\right]\left(\mathrm{SiO}_{4}\right)_{2}\left(\mathrm{Si}_{3} \mathrm{O}_{10}\right)(\mathrm{OH})_{6}$. The simplified formula is $\mathrm{Ca}_{4}\left[\left(\mathrm{Al}, \mathrm{Mn}^{3+}, \mathrm{Fe}^{3+}\right)_{5} \mathrm{Mg}\right]\left(\mathrm{VO}_{4}\right)\left(\mathrm{SiO}_{4}\right)_{2}$ $\left(\mathrm{Si}_{3} \mathrm{O}_{10}\right)(\mathrm{OH})_{6}$.

The chemical composition of the ardennite-series minerals assessed in this study varied among veins, and their chemical variation is shown in Figure 4. Cations at the T4 sites are evidently not correlated with the $\mathrm{Ca} /$ ${ }^{\mathrm{A}}\left(\mathrm{Ca}+\mathrm{Mn}^{2+}\right)$ ratio. The $\mathrm{V}$ content always exceeds 0.5 apfu, while As and $\mathrm{Si}$ are found to be present at only minor concentrations at the T4 sites (Fig. 4a). Although the $\mathrm{Al}$ content decreases with increasing the $\mathrm{Ca}$ ratio, $\mathrm{Al}$ is the dominant trivalent cation at the $\mathrm{M}$ sites (Fig. 4b). $\mathrm{Mn}^{3+}$ is the second most common trivalent cation at the $\mathrm{M}$ sites, and its value increases somewhat with increasing the $\mathrm{Ca}$ ratio. $\mathrm{Fe}^{3+}$ is present at similar levels to $\mathrm{Mn}^{3+}$ at the $\mathrm{Ca}$ ratios below 0.5 but exhibits essentially no correlation with the Ca ratio. $\mathrm{Mn}^{3+}+\mathrm{Fe}^{3+}$ content correlates with the $\mathrm{Ca}$ ratio, and it continuously varies from 1 to 2 apfu with increasing the Ca ratio (Fig. $4 \mathrm{~b}$ ). $\mathrm{Mg}$ is the dominant divalent cation at the $M$ sites (Fig. 4c) and always has a content greater than 0.5 apfu. Although the correlation between $\mathrm{Mg}$ content and the $\mathrm{Ca}$ ratio is very weak, $\mathrm{Mg}$ 

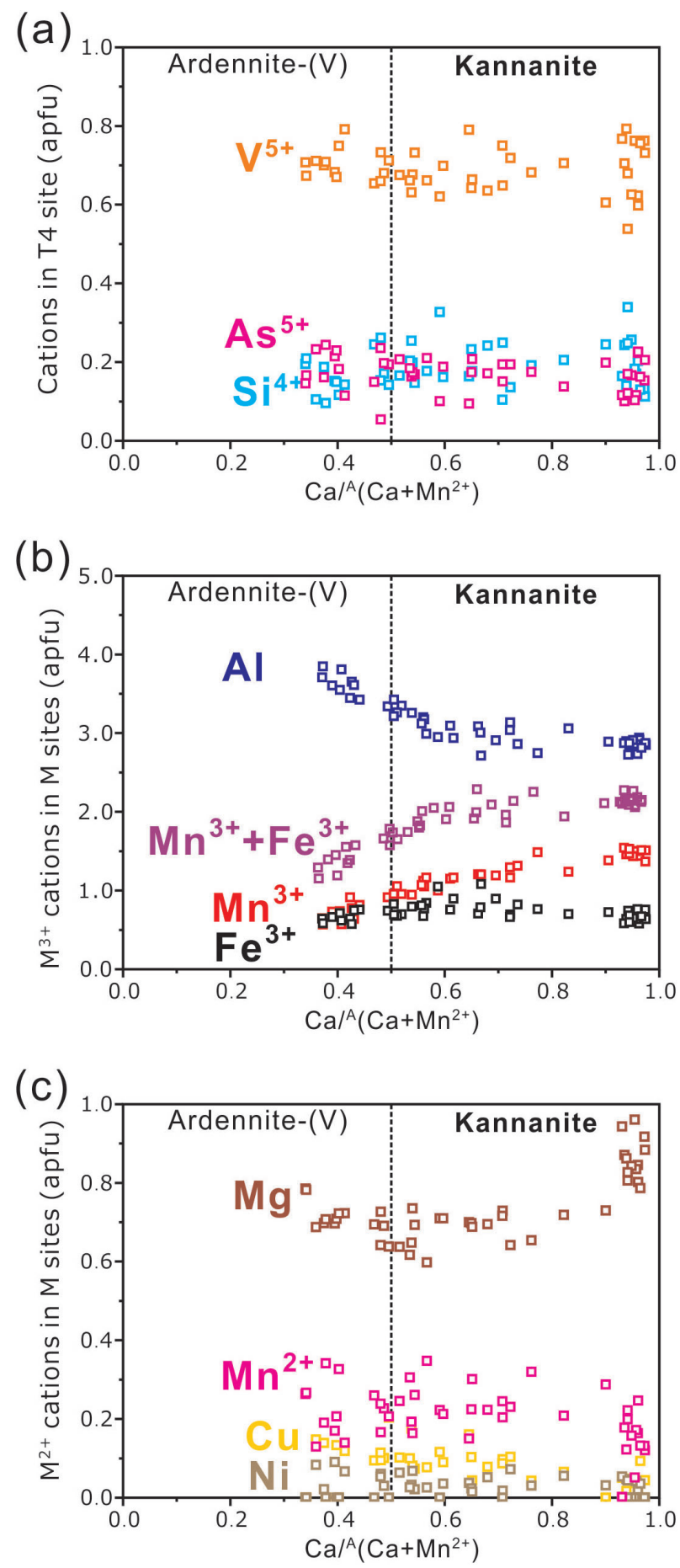

Figure 4. Compositional variations of the ardennite-series minerals of (a) cations in $\mathrm{T} 4$ site, (b) $\mathrm{M}^{3+}$ cations in $\mathrm{M}$ sites, and $\mathrm{M}^{2+}$ cations in $\mathrm{M}$ sites on $\mathrm{Ca} /{ }^{A}\left(\mathrm{Ca}+\mathrm{Mn}^{2+}\right)$.

content is particularly high for high Ca ratios. $\mathrm{Mn}^{2+}$ is the second most common divalent cation at the $\mathrm{M}$ sites and shows no relationship with the $\mathrm{Ca}$ ratio. $\mathrm{Cu}$ and $\mathrm{Ni}$, both of which are relatively small divalent cations, exhibit no correlations with the Ca ratio.
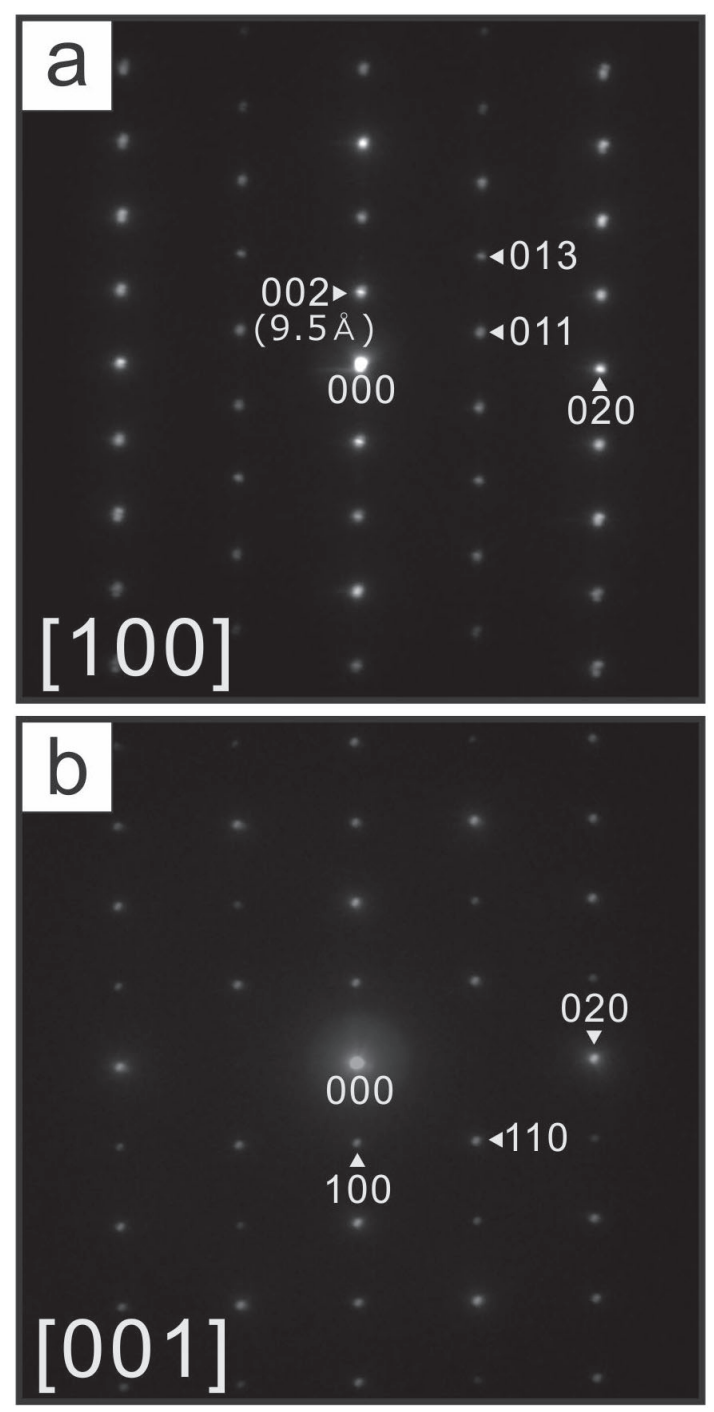

Figure 5. Selected area electron diffraction patterns for kannanite: (a) [100], and (b) [001] directions.

\section{CRYSTALLOGRAPHY}

Kannanite is present within the quartz vein in the ore sample as aggregates of fine grains up to $15 \mu \mathrm{m}$ in size, and this small grain size precluded single-crystal $\mathrm{X}$-ray analysis. Instead, the crystal structure was examined by transmission electron microscopy (TEM) and powder Xray diffraction (XRD).

The $c$ periodicity and the space group of kannanite were confirmed by TEM (JEOL-2010F, operating at 200 $\mathrm{kV}$ ) prior to XRD analysis. Samples were prepared by Ar milling using a JEOL Ion-Slicer (EM-09100IS). Figure 5 shows selected area electron diffraction patterns obtained along the [100] and [001] directions. The [100] pattern shows $00 l$ reflection spots at $l=2 \mathrm{n}$, and no streaking is apparent. The $c$ period calculated from the 002 reflection 
Table 2. X-ray powder diffraction data for kannanite

\begin{tabular}{|c|c|c|c|c|c|c|c|}
\hline$I / I_{0}$ & $h k l$ & $d_{\text {obs. }}(\AA)$ & $d_{\text {calc. }}(\AA)$ & $I / I_{0}$ & $h k l$ & $d_{\text {obs. }}(\AA)$ & $d_{\text {calc. }}(\AA)$ \\
\hline 16 & 100 & 8.889 & 8.802 & 13 & 220 & 2.486 & 2.484 \\
\hline 11 & 101 & 8.024 & 8.036 & 17 & 222 & 2.401 & 2.402 \\
\hline 7 & 103 & 5.134 & 5.135 & 25 & 117 & 2.370 & 2.370 \\
\hline 18 & 110 & 4.967 & 4.967 & 19 & 216,008 & 2.359 & $2.360,2.3603$ \\
\hline 8 & 111 & 4.790 & 4.804 & 37 & 207 & 2.306 & 2.305 \\
\hline 34 & 004 & 4.720 & 4.721 & 25 & 401 & 2.205 & 2.205 \\
\hline 12 & 200 & 4.439 & 4.440 & 13 & 026 & 2.170 & 2.170 \\
\hline 15 & 112 & 4.392 & 4.396 & 16 & 403,321 & 2.093 & $2.094,2.093$ \\
\hline 20 & 201 & 4.327 & 4.322 & 32 & 208 & 2.083 & 2.084 \\
\hline 19 & 202 & 4.017 & 4.018 & 23 & 225 & 2.074 & 2.075 \\
\hline 19 & 113 & 3.899 & 3.899 & 10 & 109 & 2.042 & 2.042 \\
\hline 17 & 203 & 3.627 & 3.628 & 9 & 316 & 2.030 & 2.029 \\
\hline 9 & 114 & 3.422 & 3.422 & 5 & 404 & 2.009 & 2.009 \\
\hline 37 & 204 & 3.234 & 3.234 & 4 & 127 & 1.956 & 1.955 \\
\hline 11 & 015 & 3.200 & 3.195 & 5 & 131 & 1.938 & 1.938 \\
\hline 6 & 213 & 3.102 & 3.104 & 6 & 405 & 1.915 & 1.914 \\
\hline 100 & 115,020 & 3.001 & $3.006,2.996$ & 4 & 209 & 1.897 & 1.897 \\
\hline 30 & 300 & 2.963 & 2.960 & 16 & 028 & 1.854 & 1.854 \\
\hline 18 & 301 & 2.930 & 2.924 & 12 & 325 & 1.840 & 1.839 \\
\hline 13 & 205 & 2.876 & 2.877 & 6 & 1110 & 1.765 & 1.765 \\
\hline 26 & 022 & 2.857 & 2.856 & 6 & 502 & 1.746 & 1.745 \\
\hline 35 & 121 & 2.809 & 2.807 & 7 & 2010 & 1.737 & 1.738 \\
\hline 66 & 122 & 2.715 & 2.719 & 7 & 135 & 1.731 & 1.732 \\
\hline 67 & 116,310 & 2.658 & $2.658,2.6539$ & 5 & 407 & 1.714 & 1.714 \\
\hline 22 & 311 & 2.628 & 2.628 & 14 & 511 & 1.694 & 1.696 \\
\hline 22 & 206 & 2.568 & 2.568 & 19 & 408 & 1.617 & 1.617 \\
\hline 47 & 024 & 2.531 & 2.530 & 8 & 0012 & 1.574 & 1.574 \\
\hline
\end{tabular}

$a=8.8802(14), b=5.9919(13), c=18.882(3) \AA, V=1004.7(3) \AA^{3}$

is approximately $19 \AA$, corresponding to that of ardennite-series minerals. The extinction rules for the [100] and [001] directions are $k+l=$ odd, $k=$ odd, and $l=$ odd for the $0 k l, 0 k 0$, and $00 l$ reflections, respectively, which are also in agreement with the Pnmm space group for ardennite-series minerals. These data confirm that kannanite is a member of the ardennite series.

Subsequent to the above analysis, an $80 \mu \mathrm{m}^{2}$ sample of the quartz vein containing kannanite that had just been analyzed was crushed and pelletized using a diamond anvil. The obtained sample was placed on Kapton tape and XRD data were collected using a synchrotron $\mathrm{X}$-ray source on the NE1 beam line at the Photon Factory Advanced Ring (PF-AR) institute, KEK, Japan. This source provided a $30 \mu \mathrm{m}$ diameter collimated beam of monochromatized $\mathrm{X}$-rays $(\lambda=0.4183 \AA)$. The XRD spectra were collected by the Debye-Scherrer method, recorded via an imaging plate detector, and then converted to conventional one-dimensional profiles using the IPAnalyzer and PDindexer software packages (Seto et al. 2010). The resulting data excluding quartz reflections are summarized in Table 2. The seven strongest lines in the powder XRD pattern [d in $\left.\AA\left(I / I_{0}\right)(h k l)\right]$ were 3.234(37)(204), 3.001(100)(115, 020), 2.809(35)(121), 2.715(66)(122), 2.658(67)(116, $310), 2.531(47)(024)$, and 2.306(37)(207). Based on these data, kannanite can be indexed to the orthorhombic Pnmm space group, and the unit cell parameters as refined from the powder data are $a=8.8802(14) \AA, b=5.9919$ (13) $\AA$, $c=18.882(3) \AA$ and $V=1004.7(3) \AA^{3}$. The $a: b: c$ ratio calculated from the above unit cell parameters is 1.48:1:3.15.

\section{DISCUSSION}

Ardennite-series minerals are classified in terms of cations in A, M, and T4 site (Fig. 1). The T4 site is preferentially occupied by As or V, and kannanite is V-dominant species (Fig. 4a). There are two $\mathrm{A}$ sites for $\mathrm{A}^{2+}$ cations and kannanite is characterized by $\mathrm{Ca}$ dominancy (Table 1). In three M sites, the M1 and M2 sites are occupied only by trivalent cations, and the M3 site is shared by 
both trivalent and divalent cations (Fig. 1). In kannanite, the half of M3 site is occupied by Mg and small amount of $\mathrm{Mn}^{2+}$ (Fig. 4c), and other half in M3 and M1 and M2 sites should be filled by the trivalent cations. The order of volume in the $\mathrm{M}$ sites is M3 > M1 > M2 in the case of ardennite-(As) (Nagashima and Armbruster, 2010). If kannanite structure also shares its characteristics, larger cations such as $\mathrm{Mn}^{3+}$ and $\mathrm{Fe}^{3+}$ included in kannanite may prefer M3 and M1 sites. However, the single crystal XRD study could not be determined due to the small size in this study. The order of amount of the trivalent cations in kannanite is $\mathrm{Al}>\mathrm{Mn}^{3+}>\mathrm{Fe}^{3+}$, and $\mathrm{Al}$ is the dominant compared to $\mathrm{Mn}^{3+}+\mathrm{Fe}^{3+}$ (Fig. 4b). Therefore, the simplified formula of kannanite is represented as $\mathrm{Ca}_{4}\left[\left(\mathrm{Al}, \mathrm{Mn}^{3+}\right.\right.$, $\left.\left.\mathrm{Fe}^{3+}\right)_{5} \mathrm{Mg}\right]\left(\mathrm{VO}_{4}\right)\left(\mathrm{SiO}_{4}\right)_{2}\left(\mathrm{Si}_{3} \mathrm{O}_{10}\right)(\mathrm{OH})_{6}$, which is distinguishable from ardennite- $(\mathrm{V}) \mathrm{Mn}_{4}^{2+}\left(\mathrm{Al}_{5} \mathrm{Mg}\right)\left(\mathrm{VO}_{4}\right)\left(\mathrm{SiO}_{4}\right)_{2}$ $\left(\mathrm{Si}_{3} \mathrm{O}_{10}\right)(\mathrm{OH})_{6}$. A follow-up crystallographic study for site assignment is expected in order to better understand the crystal chemistry of ardennite-series minerals in the future.

\section{ACKNOWLEDGMENTS}

Powder XRD data were acquired at KEK (Proposal no. 2015G522). This work was supported by a Grant-in-Aid for Young Scientists B (Grant No. JP15K17785) from the Japan Society for the Promotion of Science. The authors are also grateful to the anonymous referees of this manuscript for their constructive reviews.

\section{SUPPLEMENTARY MATERIAL}

Color version of Figures 2 is available online from https://doi.org/10.2465/jmps.180103.

\section{REFERENCES}

Banno, Y., Mizuno, K. and Miyazaki, K. (2010) Geology of the Ozu district. Quadrangle Series, 1:50,000, pp. 58, Geological
Survey of Japan, AIST.

Barresi, A.A., Orilandi, P. and Pasero, M. (2007) History of ardennite and the new mineral ardennite-(V). European Journal of Mineralogy, 19, 581-587.

Donnay, G. and Allmann, R. (1968) $\mathrm{Si}_{3} \mathrm{O}_{10}$ groups in the crystal structure of ardennite. Acta Crystallographica, B24, 845-855.

Frost, R.L., Lópe, A., Scholz, R. and Gandini, A.L. (2014) Avibrational pectroscopic study of the silicate mineral ardennite(As). Spectrochimica Acta Part A: Molecular and Biomolecular Spectroscopy, 118, 987-991.

Mandarino, J.A. (1981) The Gladstone-Dale relationship: part IV. The compatibility concept and its application. Canadian Mineralogist, 19, 441-445.

Momma, K. and Izumi, F. (2011) VESTA 3 for three-dimensional visualization of crystal, volumetric and morphology data. Journal of Applied Crystallography, 44, 1272-1276.

Nagashima, M. and Armbruster, T. (2010) Ardennite, tragalloite and mediate: structural control of $\left(\mathrm{As}^{5+}, \mathrm{V}^{5+}, \mathrm{Si}^{4+}\right) \mathrm{O}_{4}$ tetrahedra in silicates. Mineralogical Magazine, 74, 55-71.

Orlandi, P., Biagioni, C., Pasero, M. and Mellini, M. (2013) Lavoisierite, $\mathrm{Mn}_{8}^{2+}\left[\mathrm{Al}_{10}\left(\mathrm{Mn}^{3+} \mathrm{Mg}\right)\right]\left[\mathrm{Si}_{11} \mathrm{P}\right] \mathrm{O}_{44}(\mathrm{OH})_{12}$, a new mineral from Piedmont, Italy: the link between "ardennite" and sursassite. Physics and Chemistry of Minerals, 40, 239-249.

Pasero, M. and Reinecke, T. (1991) Crystal chemistry, HRTEM analysis and polytypic behavior of ardennite. European Journal of Mineralogy, 3, 819-830.

Pasero, M., Reinecke, T. and Fransolet, A.M. (1994) Crystal structure refinements and compositional control of $\mathrm{Mn}-\mathrm{Mg}-\mathrm{Ca}$ ardennites from the Belgian Ardennes, Greece, and the western Alps. Neues Jahrbuch für Mineralogie-Abhandlungen, 166, 137-167.

Sakakibara, M., Oyama, Y., Umeki, M., Sakakibara, H., Shino, H. and Goto, S. (1998) Geotectonic division and regional metamorphism of Northern Chichibu Belt in western Shikoku. The Journal of Geological Society of Japan, 104, 604-622 (Japanese with English abstract).

Seto, Y., Nishio-Hamane, D., Nagai, T. and Sata, N. (2010) Development of a software suite on X-ray diffraction experiments. The Review of High Pressure Science and Technology, 20, 269-276.

Manuscript received January 3, 2018

Manuscript accepted August 19, 2018

Manuscript handled by Akira Yoshiasa 